\title{
95 Percent Maximal Inhibitory Concentration Subject Result Measurement
}

National Cancer Institute

\section{Source}

National Cancer Institute. 95 Percent Maximal Inhibitory Concentration Subject Result Measurement. NCI Thesaurus. Code C116251.

A measurement of titer of a viral organism or biological/biochemical reaction that has been exposed to a concentration of a specific drug expected to produce $95 \%$ inhibition of the standard growth of the viral organism, or of a reaction. 